Report No.

WR-B-96-O?
U.S. Department of Inersy

Office of Inspector General

Report on
Subcontracting Practices
at the ITevada Operations
Office and its Management
and Operating Contractor

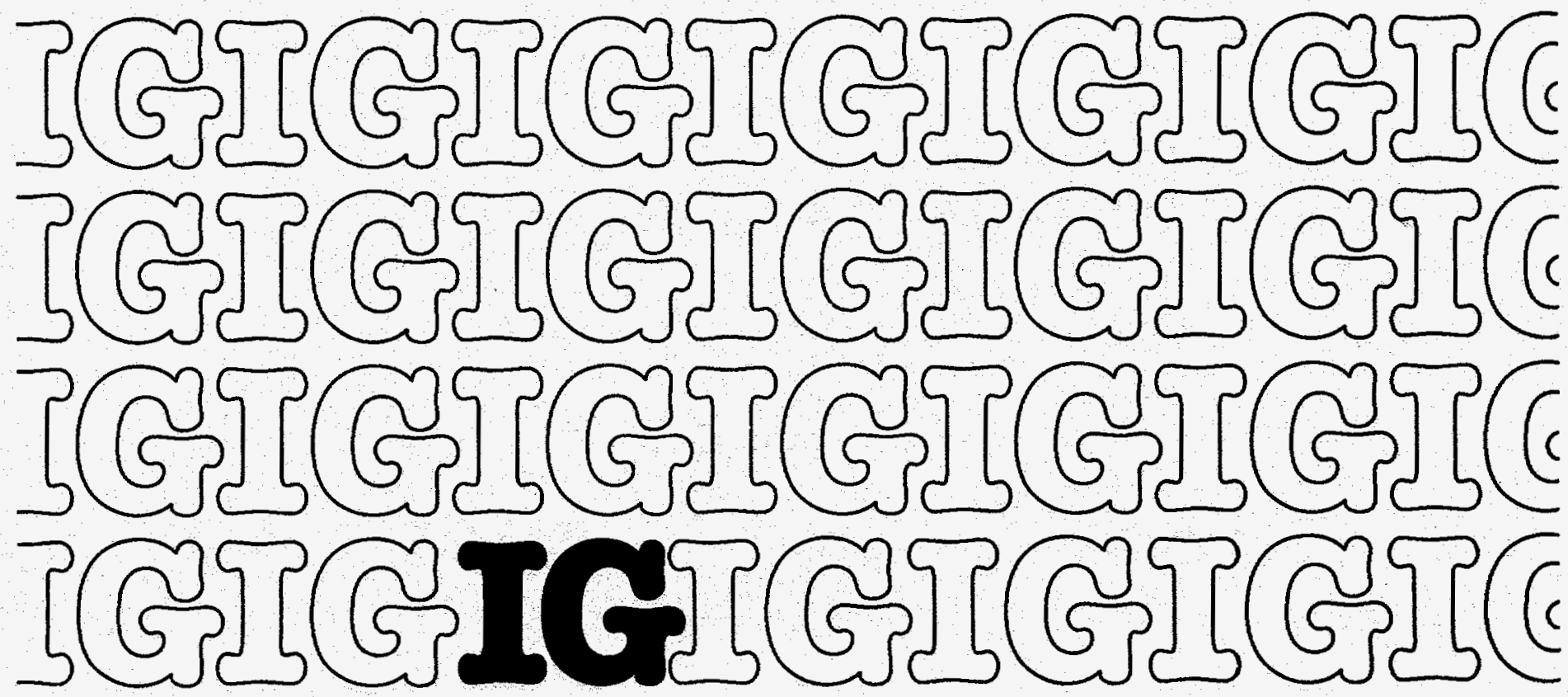


The Office of Inspector General wants to make the distribution of its reports as customer friendly and cost effective as possible. Therefore, this report will be available electronically through the Internet five to seven days after publication at the following alternative addresses:

$$
\begin{aligned}
& \text { Department of Energy Headquarters Gopher } \\
& \text { gopher.hr.doe.gov } \\
& \text { Department of Energy Headquarters Anonymous FTP } \\
& \text { vml.hqadmin.doe.gov } \\
& \text { Department of Energy Human Resources and Administration } \\
& \text { Home Page } \\
& \text { http://ww.hr.doe.gov/refshelf.html }
\end{aligned}
$$

Your comments would be appreciated and can be provided on the Customer Response Form attached to the report.

This report can be obtained from the U.S. Department of Energy

office of Scientific and Technical Information P.0. Box 62

Oak Ridge, Tennessee 37831 
U.S. DEPARTMENT OF ENERGY

OFFICE OF INSPECTOR GENERAL

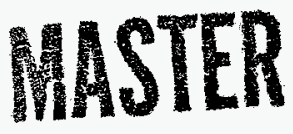

DISTRIBUTION OF THIS DOCUMENT IS UNLIMITED 35

Report Number: WR-B-96-07

Date of Issue: May 10, 1996
Western Regional Audit office

Albuquerque, New Mexico 87185 


\section{SUBCONTRACTING PRACTICES AT THE NEVADA OPERATIONS OFFICE AND ITS MANAGEMENT AND OPERATING CONTRACTOR}

\section{TABLE OF CONTENTS}

Page

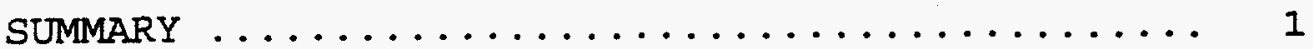

PART I - APPROACH AND OVERVIEW ............... 2

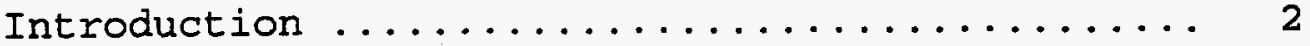

Scope and Methodology ................. 2

Background $\ldots \ldots \ldots \ldots \ldots \ldots \ldots \ldots \ldots \ldots \ldots \ldots \ldots \ldots \ldots \ldots \ldots \ldots$

Observations and Conclusions ............ 3

PART II - FINDING AND RECOMMENDATIONS ............ 5

Subcontracts Awarded in Support of Department Program offices ..................... 5

PART III - MANAGEMENT AND AUDITOR COMMENTS ........... 9 



\author{
U.S. DEPARTMENT OF ENERGY \\ OFFICE OF INSPECTOR GENERAL \\ OFFICE OF AUDIT SERVICES \\ WESTERN REGIONAL AUDIT OFFICE
}

\title{
SUBCONTRACTING PRACTICES AT THE NEVADA OPERATIONS OFFICE AND ITS MANAGEMENT AND OPERATING CONTRACTOR
}

Audit Report Number: WR-B-96-07 May 10, 1996

\section{SUMMARY}

The Department of Energy (Department), Nevada Operations Office (Nevada) is responsible for following established policy in obtaining necessary support services through its Contract Management Division. The objective of the audit was to determine whether Nevada and its Management and operating (M\&O) contractors were following Federal and Department policies with regard to directed support service subcontracts.

The audit showed that program offices in Nevada and Headquarters were directing the Nevada M\&O contractor to award subcontracts to specific companies or individuals. The subcontractors reported either directly to a program office or to a national laboratory. Furthermore, the subcontractors' work products were delivered directly to the requesting program office. The M\&O contractor had only administrative responsibility for the subcontracts awarded. This occurred because Nevada had not established adequate internal controls over the process of procuring support service. As a result, the $M \& O$ contractor was paid a higher award fee for managing the Department's contracts and may have incurred additional costs in staffing its procurement office. We recommended that the Manager, Nevada Operations office, discontinue directed support service subcontracts to its M\&O contractor and act to strengthen internal controls over subcontracting.

Nevada management partially concurred with the recommendations but did not believe the directed procurements cited in the report were inappropriate. Details of management's comments and our responses are included in Part III.

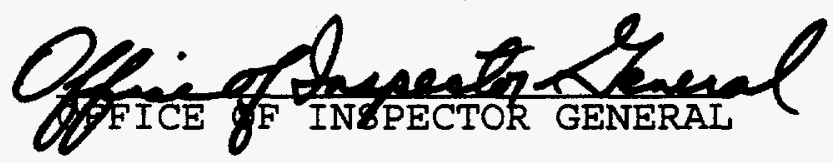




\section{PART I \\ APPROACH AND OVERVIEW}

\section{INTRODUCTION}

The Nevada Operations Office is responsible for ensuring that its program offices follow established policy and obtain necessary support services through Nevada's Contract Management Division. The objective of the audit was to determine whether Nevada and its M\&O contractor were following Federal and Department policies with regard to directed support service subcontracts. More specifically, we sought to determine if Nevada's M\&O contractor was used to procure support services outside the normal procurement process.

\section{SCOPE AND METHODOLOGY}

The audit was conducted at Las Vegas, Nevada, from March 1995 through September 1995 and covered subcontracts in effect during the period October 1, 1992, through April 30, 1995. Audit work was performed at Nevada's Contract Management Division and at the procurement offices of EG\&G Energy Measurements (EG\&G/EM), Raytheon Services Nevada (Raytheon), and Reynolds Electrical and Engineering Company, Inc. (Reynolds).

To accomplish the audit objective, we interviewed key Department and contractor personnel and reviewed:

- Federal and departmental regulations, Department memoranda, and M\&O contractor policies and procedures for subcontracting;

- prior reviews and reports issued by Nevada concerning contracting or subcontracting; and,

- contract files regarding the scope of work, period of performance, dollar amount, extent of competition, justifications for sole source, and modifications to the original contracts or subcontracts.

The total number of subcontracts in the universe was 2,066, valued at approximately $\$ 221$ million. We selected a judgmental sample of 47 subcontracts valued at $\$ 22.7$ million. The sample of 47 subcontracts included 19 subcontracts over $\$ 500,000$ (19 of 63 or 30 percent) and 28 subcontracts under $\$ 500,000$.

The audit was conducted in accordance with generally accepted Government auditing standards for performance audits and included tests of internal controls and compliance with laws and regulations, to the extent necessary, to satisfy the objective of the audit. Accordingly, we assessed the significant internal controls with respect to the subcontracting process, including 
identification and review of internal controls in the selection and administration of subcontracts. We did not rely extensively on computer-processed data and, therefore, did not fully examine the reliability of that data. Because our review was limited, it would not necessarily have disclosed all internal control deficiencies that may have existed at the time of our audit. Exit conferences were held on November 15, 1995, and March 12, 1996, with the Chief Financial officer and the Director, Contract Management Division.

\section{BACKGROUND}

Recently, the Office of Inspector General (OIG) initiated a number of audits on aspects of subcontracting at various M\&O contractors. A June 1995 audit report titled Consultant Subcontracting at the Idaho National Engineering Laboratory (WR-B-95-07), for example, discussed subcontracting practices that were neither competitive nor objective and that were directed support service subcontracts. In February 1996, the OIG issued a second report titled Consultant Agreements at Los Alamos National Laboratory (WR-B-96-06), which questioned the adequacy of sole source justifications used by the M\&O contractor at Los Alamos.

Prior to January 1, 1994, each of Nevada's three M\&O contractors had its own procurement office, and each administered its own contracts. In January 1994, Reynolds and EG\&G/EM consolidated procurement functions under one director in order to reduce overhead costs. In March 1995, Raytheon's procurement office joined the consolidated procurement function. As a result, one procurement office now provides services for all three contractors. Since the period covered by the audit, October 1, 1992, through April 30, 1995, crossed the consolidation period, we have used the term "M\&O contractor" to refer to all participants in the joint procurement office.

\section{OBSERVATIONS AND CONCLUSIONS}

During the audit, we noted that the number of directed support service subcontracts was decreasing. The M\&O contractor also strengthened its internal controls by requiring program managers to assure that the procurement requests were within the scope of the M\&O's mission.

Despite these improvements, however, the audit showed that Nevada's M\&O Contractor obtained support services for both Nevada and Headquarters program offices. Directed support service subcontracts continued to occur because internal controls at Nevada and at the M\&O contractor were inadequate. We recommended strengthening these controls to ensure that program offices cannot go directly to the M\&O contractor to obtain support services. We also recommended that the program offices be instructed to obtain support services through Nevada's Contract Management Division. Nevada partially concurred with the 
recommendations, but did not concur with the facts and conclusions as presented.

Procurement officials at Department Headquarters, on the other hand, expressed concern about the continuing practice of directing M\&O contractors to procure support services on behalf of the Department. According to these officials, with whom we discussed the specific cases cited in this report, circumventing Department procurement policy could jeopardize the Department's credibility with oversight organizations and expose the Department to criticism.

We consider the inadequacy of controls over directed support service subcontracts an internal control weakness that Nevada should consider in preparing its yearend assurance memorandum. 


\section{PART II}

\section{FINDING AND RECOMMENDATIONS}

\section{Subcontracts Awarded in Support of Department Program offices}

\section{FINDING}

Department and Federal policies state that it is inappropriate for program offices to use M\&O contractors to obtain direct contract support for their programs. When direct contract support is necessary, program offices are required to use the Department's - not the M\&O contractor's - - procurement procedures and personnel. Nevada's M\&O contractor, however, awarded $\$ 2.5$ million from October 1, 1992, through April 30, 1995, in subcontracts that provided direct support to Nevada and Headquarters program offices. This occurred because Nevada and its M\&O contractor had inadequate internal controls to ensure that Department policy was carried out. As a result, the Department paid more in M\&O contractor award fees than was necessary. Furthermore, the M\&O contractor was procuring services unrelated to its mission.

\section{RECOMMENDATIONS}

We recommend that the Manager, Nevada Operations Office, strengthen internal controls by:

1. strengthening existing procedures that require program offices to submit procurement requests through Nevada's Contract Management Division;

2. discontinuing the use of the M\&O contractor to acquire services that directly support program offices; and

3. instructing the $M \& O$ contractor to augment, if necessary, and enforce its procedures aimed at ensuring that only procurement requests within the contractor's mission are accepted.

\section{MANAGEMENT REACTION}

Nevada management concurred with the first recommendation, partially concurred with the second, and did not concur with the third recommendation. Management comments and our responses are summarized in Part III.

\section{DETAILS OF FINDING}

In August 1981, the Assistant Secretary for Management and Administration issued a memorandum entitled "Directed Subcontracts for Support Services." This memorandum stated that the only support service contracts which should be placed by M\&O 
contractors are contracts to meet their own support service requirements. This memorandum re-emphasized the Federal policy that $M \& O$ contractors do not buy for Federal agencies. In June 1993, the Acting Assistant Secretary for Human Resources and Administration issued a memorandum with the same title which re-emphasized the need to be careful when dealing with M\&O procurement offices. This memorandum stated that using $M \& O$ contractors to acquire support service for the Department places the contractor into the role of a mere procurement office and avoids the safeguards provided by the normal Department procurement process. Further, in January 1996, the Deputy Assistant Secretary for Procurement and Assistance Management once again re-emphasized the fact that DOE program offices should not use M\&O contractors to acquire needed support services. In addition, the Deputy Assistant Secretary warned M\&O contractors' purchasing managers that acquisitions that do not support the mission of their contract are unacceptable and that the purchasing managers will be held accountable for any such purchases.

\section{DIRECTED SUPPORT SERVICE SUBCONTRACTS}

Department guidance on this issue has been consistent since 1981, with the January 1996 memorandum serving as the latest re-emphasis from Department Headquarters. The audit disclosed, however, that in spite of long-standing Departmental policy, 14 of 47 subcontracts (30 percent) awarded by Nevada's M\&O contractors were directed by the Department. The total value of these directed subcontracts was $\$ 2.5$ million.

In each of the 14 cases, the M\&O contractor had only administrative responsibilities - - such as awarding the subcontract and paying vouchers - - and had no substantive involvement in technical matters. Instead, the subcontractors directly supported the program offices (Nevada and Headquarters) or a national laboratory. Subcontractors, moreover, received their work assignments and directions from Department or laboratory officials. The subcontractors' work products were provided directly to the Department or the laboratory.

For example, the M\&O contractor awarded 4 subcontracts, for a total of $\$ 2.3$ million, involving the preparation of threat assessments. The subcontractors received directions for the work from either the office of Non-Proliferation and National security (a Headquarters program office) or a national laboratory. The M\&O contractor had only subcontract administrative responsibilities, such as awarding the subcontract, paying the vouchers, and reviewing security plans and procedures provided on the subcontractors' building and telephone systems. The M\&O contractor did not direct any of the subcontractors' work nor was it the main recipient of any of the subcontractors' work products. The threat assessment reports went directly to the Department. 
In addition, the M\&O contractor also issued 9 subcontracts, totaling $\$ 143,000$, to individuals to participate on a panel on behalf of a Department program office. The M\&O contractor's only responsibility in these subcontracts was awarding the subcontract and paying the vouchers. The panel's reports were forwarded to the Department, not to the M\&O contractor.

\section{APPROVALS AND INTERNAL CONTROLS OVER SUBCONTRACTING}

The directed support service subcontracts occurred because Nevada had not established an adequate system of internal controls over the process of procuring support services; in addition, the M\&O contractor's internal controls were not sufficient to identify the support service requests for program offices. Although Department policy on directed subcontracts for support service is clear in not allowing program offices to use the M\&O contractors to acquire support service, the program offices continued acquiring those services through the M\&O contractors.

Department officials stated that the major reason for using the M\&O contractor's procurement office was that the contractor's processes were quicker and easier. Further, program managers told us they have obtained direct support in this manner since the early 1980s. However, both the contractors and Nevada program officials acknowledged that directed support service subcontracts of this nature were inconsistent with Department policy.

Similarly, the M\&O contractor did not have sufficient controls in place to ensure that only procurement requests within its scope of work were allowed to proceed through the procurement process. Instead, the M\&O contractor accepted procurement requests from program offices at Nevada and Headquarters without comparing the requested service to its contractor's mission. Although some controls were implemented during our audit, directed support service subcontracts still occurred.

\section{INCREASE OF NEVADA'S COST FOR THE M\&O CONTRACTOR}

The Department annually calculates an award fee for each of the M\&O contractors. This award fee is based on performance and the total expenditures for the fiscal year involved. Since the Department required the $M \& O$ contractor to acquire subcontract services which were not a part of its mission, the M\&O contractor actually received award fees that were greater than necessary. We discussed this matter with Nevada staff members from the Chief Financial officer Division and the Program Management Division to determine what award fee could be attributed to subcontract administration. The personnel responded that it was impossible to segregate the percentage of award fee that could be attributed to contract administration because contract administration was a part of the administration award pool. 
A number of other effects could also occur. As described earlier, for example, the M\&O contractor was awarding subcontracts for work that was outside its mission responsibilities. Moreover, the contractor's procurement function was established to assist the contractor in the timely completion of its mission, not to obtain support services for Headquarters or Nevada program offices. Such activity could result in the M\&O contractor requesting additional staffing or maintaining staff beyond its actual needs. 


\section{$\underline{\text { PART III }}$ \\ MANAGEMENT AND AUDITOR COMMENTS}

In responding to the official Draft Report, management concurred with the first recommendation, partially concurred with the second, and did not concur with the third. In addition, management provided supplemental information regarding its position on directed procurements.

Recommendation 1

Management Comments: Management concurred with the recommendation to strengthen existing procedures that required program offices to submit procurement requests through Nevada's Contract Management Division. Management further stated that the Director of the Contract Management Division would send a memorandum to all program offices re-emphasizing the requirement to send all procurement requests to the Contract Management Division.

Auditor Comments: Management's proposed corrective action is responsive to the recommendation.

\section{Recommendation 2}

Management Comments: Management partially concurred with the recommendation to discontinue the use of the M\&O contractor to acquire services that directly support program offices. To the extent that Department Headquarters program offices request support, Nevada agrees with the recommendation. However, Nevada believes that procurements directed by its own program officials can be appropriate, so long as they are consistent with DOE Order $4200.1 \mathrm{C}$, Competition In Contracting.

Management stated that the contractor's scope of work included the specific areas that were the purposes of the subcontracts discussed in this report. Management contends that Nevada's Contract Management Division may go to the contractor when the procurement is related to the contractor's mission and usual procedures are insufficient. Further, management did not agree that the 14 directed procurements cited in the report were inappropriate. Management contends that sole-source justifications in the contract files were sufficient evidence that the directed procurements were appropriate. Management supplied supplemental information that explained its position that the 14 subcontracts cited in the report were appropriately awarded.

Auditor Comments: Although Nevada concurred with part of this recommendation, it did not address corrective actions to eliminate future Headquarters-directed procurements. Further, DOE Order $4200.1 \mathrm{C}$ does not supersede Department guidance cited in this report respecting directed procurements. Rather, it appears 
Nevada is misinterpreting this order which allows sole-source procurements under certain circumstances that have been fully justified. According to Headquarters procurement officials, such justifications apply to work the M\&O contractor would actually perform for the Department. They would not apply to cases such as the 14 cited in the report, where the M\&O contractor had only administrative responsibilities and no substantive or technical participation. Although the contractor's scope of work included the specific areas that were the purposes of the 14 subcontracts, the contractor must have technical responsibilities and have substantive involvement for the subcontracts they issue. Lack of such participation is, in fact, strong evidence that the services contracted for were not necessary to the contractor's mission. Further, sole-source justifications in the contract files tell only why a certain contractor was chosen. They do not explain why the M\&O contractor, and not Nevada, had to procure the service. The supplemental data did not explain why the M\&O contractor should award these 14 subcontracts.

Recommendation 3

Manaqement Comments: Nevada did not concur with the recommendation to instruct the $M \& O$ contractor to augment, if necessary, and enforce its procedures aimed at ensuring that only procurement requests within the contractor's mission are accepted. Management cited DOE Order 4200.1C, Competition in contracting, as the reason for not concurring. Further, Management contends that what we have suggested would undermine the contracting officer's authority, by allowing the M\&O contractor to decide what services they will procure.

Auditor comments: The audit report did not focus on competition in contracting. In contrast, it focused on Nevada's use of the M\&O contractor's procurement office to obtain directed support service subcontracts for which the M\&O contractor had no technical or substantive involvement.

The Deputy Assistant Secretary of Procurement and Assistance Management informed M\&O contractor purchasing managers that they will be held accountable for issuing subcontracts which are not within the company's mission. This was documented to the Operations offices in a January 30, 1996, memorandum. 
Report No. WR-B-95-07

\section{CUSTOMER RESPONSE FORM}

The Office of Inspector General has a continuing interest in improving the usefulness of its products. We wish to make our reports as responsive as possible to our customers' requirements, and therefore ask that you consider sharing your thoughts with us. On the back of this form, you may suggest improvements to enhance the effectiveness of future reports. Please include answers to the following questions if they are applicable to you:

1. What additional background information about the selection, scheduling, scope, or procedures of the audit or inspection would have been helpful to the reader in understanding this report?

2. What additional information related to findings and recommendations could have been included in this report to assist management in implementing corrective actions?

3. What format, stylistic, or organizational changes might have made this report's overall message more clear to the reader?

4. What additional actions could the Office of Inspector General have taken on the issues discussed in this report which would have been helpful?

Please include your name and telephone number so that we may contact you should we have any questions about your comments.

Name Date

Telephone Organization

When you have completed this form, you may telefax it to the office of Inspector General at (202) 586-0948, or you may mail it to:

Office of Inspector General (IG-1)

U.S. Department of Energy

Washington, D.C. 20585

ATTN: Customer Relations

If you wish to discuss this report or your comments with a staff member of the Office of Inspector General, please contact Wilma slaughter at (202) 586-1924. 